\title{
General Andrew Wauchope of Niddrie Marischal. \\ A character sketch and brief historical tribute
}

Eric McPherson*

Two months after the outbreak of the Anglo-Boer War a series of battles took place which shook Britain. These were Stormberg (10 December 1899), Magersfontein (11 December 1899) and Colenso (15 December 1899). All had been reverses for the British army and had taken place within a week which became known as Black Week - a phrase coined by the British Liberal Party politician Asquith. Great Britain was regarded as having the world's most powerful army at the time and the losses suffered against the Boers resulted in humiliation and anguish for the British nation. However, nowhere was the anguish greater than in Scotland for at Magersfontein the Highland Brigade had fared badly suffering severe losses including their commander, Major-General Andrew Wauchope, killed in action. As Conan Doyle put it, "Never has Scotland had a more grievous day than this at Magersfontein. She had always given her best blood with lavish generosity for the Empire, but it may be doubted if any single battle has ever put so many families of high and low, into mourning from the Tweed to Caithness shore." (Doyle, $1900: 24)$ In the words of biographer William Baird "the empire has lost one of its noblest and best, a hero has gone down to his rest ere his full life's work was done". (Baird, 1902:196)

Although these statements may seem somewhat flowery and were expressed during a period of much patriotic fervour, they nevertheless indicate the emotional reaction to Andrew Wauchope's untimely death.

\section{Family background}

Why was it then that upon news of his death "the name of Wauchope - or 'Andy Wauchope' - was breathed with tender and affectionate regret from almost every speaker's lip? Many had fallen: it was around the General's name that grief was precipitated". (Douglas, 1904:1)

The answer lies in his character as a man which in turn was based on his family background and upbringing. Andrew Gilbert Wauchope was born at Niddrie Marischal, Midlothian, Scotland, on the 5th July, 1846. His father was Andrew Wauchope and mother Frances, daughter of Henry Lloyd, County Tipperary. The Wauchope family had been associated with Niddrie for many centuries and belonged to the landed gentry. Andy Wauchope's father was described as being "long known and respected as a kind and indulgent landlord, ever ready to give a helping hand to his tenants or to religious and philanthropic objects". It is not surprising therefore that from this genteel background he inherited this characteristic consideration for his fellow man and those under his command.

According to biographer Sir George Douglas, Andrew from his earliest years developed the characteristics of a Wauchope, somewhat modified by the Irish strain (his mother) which later showed itself specially in his gift of speech and strong though restricted sense of humour.

As a young boy he spent two years with his family at Gräfenberg in the mountains near the Prussian border. Andrew's father, who had been injured in a foxhunt, was being treated by a physician there. It was as a travelled child that he returned to his native Scotland; having also spent a winter in Nice and a visit to Florence. He was adventurous and high-spirited with a touch of mischief which, however, never overstepped the line where legitimate fun ends. (Douglas, 1904:8)

Up to the age of 10 he had received his educational instructions at home and was then enrolled at a school in Worksop, Nottinghamshire. This school, carefully selected by his mother, was unusual in that it had been founded and was being run by prominent European educational ists. His boyhood was thus a remarkable amal gamation of basically Scottish supplemented by the finer European influences. 


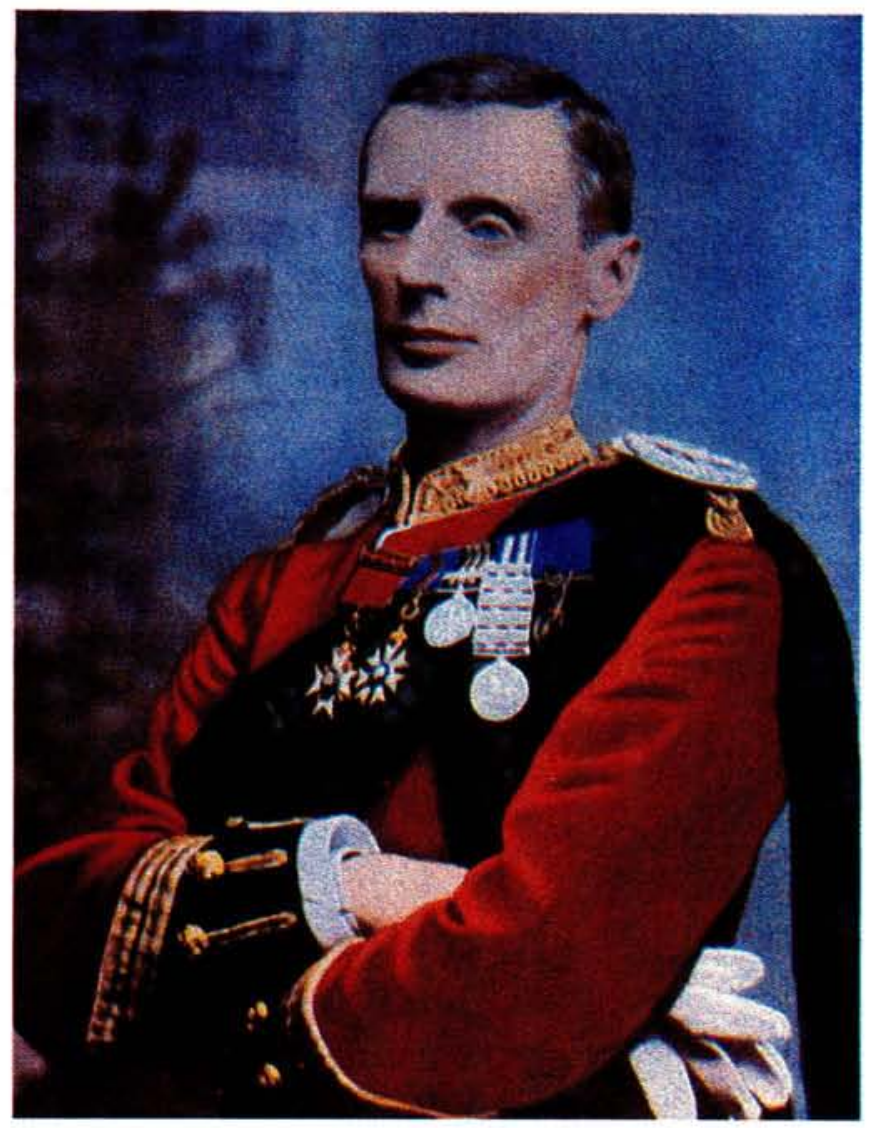

Major-General A.G. Wauchope, CB, CMG.

\section{Career prior to the Anglo-Boer War}

At an early age the young Andrew had made up his mind to go to sea and in 1858 began his training in Forster's School, Gosport. He later obtained his discharge from the Royal Navy and spent a further 3 years in Niddrie in preparation for his future in the military. In November 1865 at the age of 19 he joined the 42nd Royal Highlanders (Black Watch) at Stirling, Scotland. As a staunch Scot with a romantic inclination, the young Wauchope was inordinately proud to be a member of this élite regiment famous for its valour. He trained in Edinburgh, Aldershot and Devonport, promoted to lieutenant in 1867 and in 1870 to adjudant of his regiment.

Shortly afterwards he was posted to West Africa, participating in the Ashanti Campaign during which he was wounded. Following the Ashanti War he was posted to Malta and in 1878, after being promoted to captain, joined the Black Watch in Cyprus, where he was appointed as a commissioner in the Paphos district.

Andrew Wauchope's first contact with South
Africa was in 1880 when he was sent there at the outbreak of the First Anglo-Boer War in 1880. His activities involved communication lines and staff functions.

From 1882 to 1886 he served in Egypt and during this period was promoted to major and later lieutenant-colonel. He was promoted to the rank of colonel in 1888.

He entered politics at this stage and stood as a Liberal candidate in the Midlothian electoral division against W.E. Gladstone (1892) and succeeded in considerably reducing his opponent's former majority.

Although Andrew Wauchope had by now become a wealthy man, having succeeded to the family fortune in 1884 upon the death of his elder brother, Major William Wauchope, he nevertheless continued with his military career, returning to Egypt in 1898 and serving under General Kitchener in the successful battle of Omdurman. $\mathrm{He}$ was enthusiastically welcomed upon his return to Britain and received an honorary doctorate from Edinburgh University. 


\section{Highlights of his career}

At this stage it is appropriate to highlight some of the incidents mentioned in the biographies by George Douglas and William Baird. These serve to illustrate his character more fully. During the four years spent in the Navy, Midshipman Wauchope was well liked and according to Sir Charles Fane (a former brother-officer), was a most promising young officer, popular with all on board and a loss to the Navy when he left. It is interesting to note that other prominent British Army officers, e.g. Field-Marshall Sir George White and Sir John French, had also received their early training in the sister service.

During his stay in Cyprus, he once substituted for the chaplain at the burial of one of his men and his address and closing prayer moved many of the soldiers to tears and making a deep and lasting impression on them. However, when the occasion warranted it he could also be stern - also dry and dour when things were not going as he felt they ought to be. (Douglas, 1904:40)

One of Colonel (as he was then) Wauchope's most remarkable achievements was his short foray into politics when he contested the Midlothian parliament seat against the great Gladstone. Wauchope's first loyalty was to the Army but he also took a keen interest in political matters, though not obviously so. After much soulsearching, he was persuaded to stand as the Liberal Unionist candidate. As was his custom he worked hard to honour this responsibility. Active politics was new to him and it must be borne in mind that he was at the same time an active soldier often stationed away from this constituency. However, he was to win votes by strength of character, respectability and his obvious genuineness.

Voting was heavy, $84 \%$, and when the poll was declared on 13 July 1892, Gladstone had obtained 5845 and Wauchope 5155 . He had succeeded in reducing a previous majority of 4631 to 690 - a remarkable achievement against such a formidable opponent.

During 1898 Wauchope was again in North Africa, this time in the Sudan where he participated in the successful battle of Omdurman. He had been promoted to Brigadier-General in

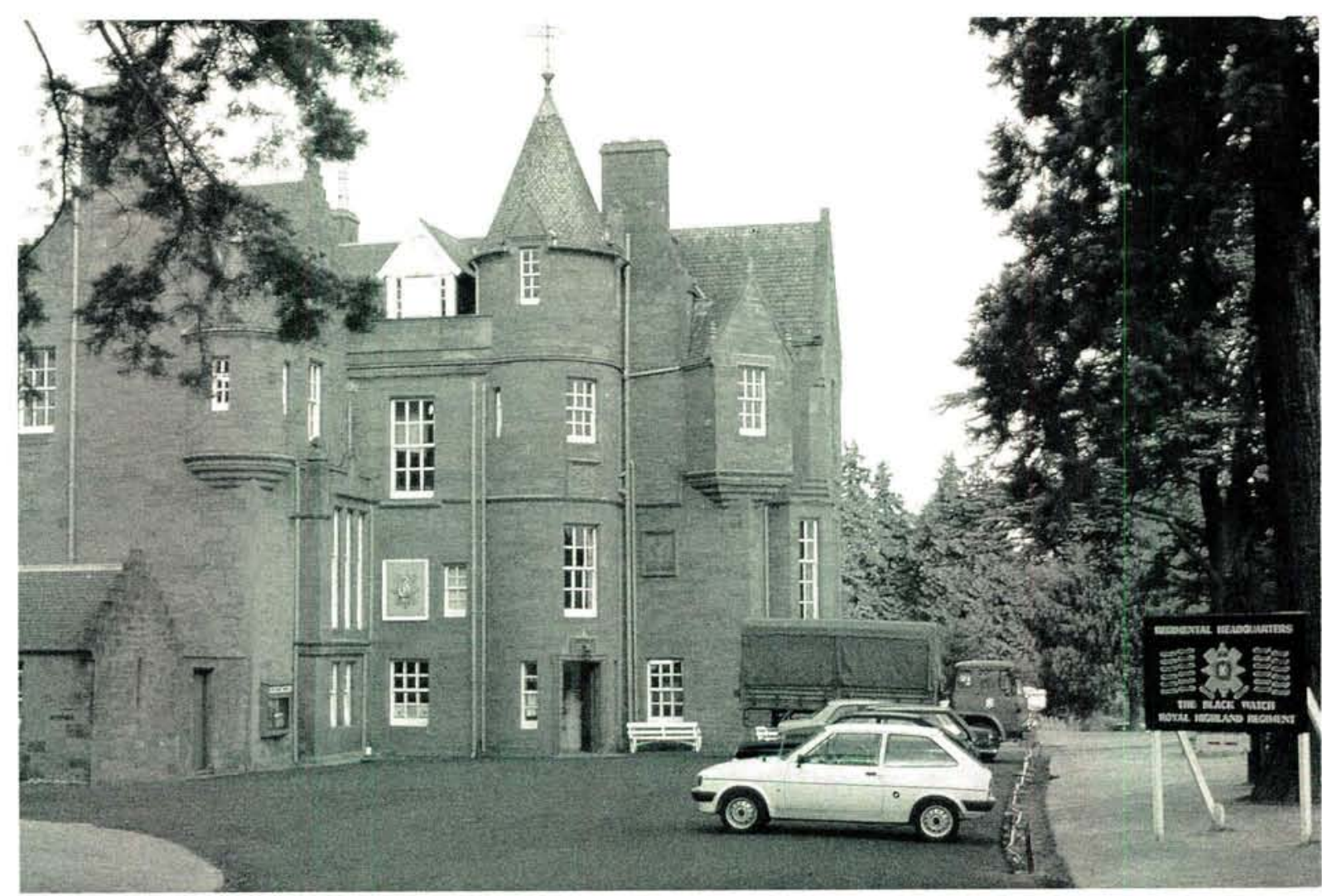

Regimental Headquarters of the Black Watch, Royal Highland Regiment at Dalhousie Castle, Perth, Scotland. The castle houses a museum which has an entire section devoted to the Transvaal Scottish Regiment, which has close ties with the Black watch. 
command of 1st British Brigade. For once he was not wounded in battle. In the Ashanti War of 1873 he had twice been wounded, once severely. In the Egyptian Campaign of 1882, he was again severely wounded. At Kirkeban in the Nile Expedition (1884-5), he was wounded yet again. As far as his personal safety was concerned, Andy Wauchope was not lucky in battle.

It is interesting to note that in the Sudan Campaign of 1898, Generals Gatacre and Lyttleton, who were present there, would also participate in the Anglo-Boer War later that year. In a letter to his wife, dated 4th September 1898, written in Khartoum, he states, "Well, we fought them (the Dervishes) yesterday, and licked their heads off: but they came on with a vengeance. I am simply worked off my legs, trying to get accounts written up ... How I long to be back! I hate war." (Douglas, 1904:356)

\section{The period immediately before the Boer War}

There is evidence that General Wauchope had been considering retiring from the Army. The tie had weakened as his old regiment, the Black Watch, was no longer under his command. He had become a man of great personal influence in his homeland and he had strong personal attachments in Niddrie and Edinburgh. The ball was at his feet politically and by no means least there was his happy home life from which he had often been separated because of his participation in various campaigns. Yet, because of his knowledge gained of South Africa during his stay there in 1880 , he was unavoidably drawn to it. He had consistently maintained since 1881 that war between England and the Boers was a matter of time. Although he believed that British subjects should have equal rights with the 'Dutch' in the Transvaal and Orange Free State, he did not believe in "trampling under foot their liberties, religion or anything which free citizens or a free state desire ..." (Douglas, 1904: 369) $\mathrm{He}$ was also of the firm conviction that in the event of war with the two republics in South Africa, the war would be a serious one, likely to occupy the country (Britain) long and severely tax her resources.

Soon after the declaration of war General Wauchope was informed that he would be given command of the Highland Brigade to be sent to Port Elizabeth. On 23 October 1899 he boarded the s.s. Aurania at Southampton. The news he was receiving on board about the war was bleak for Britain. The Boers were putting up a tremen- dous fight and the British forces had sustained heavy losses during the fighting at Glencoe, Elandslaagte and Ladysmith was under threat. General Penn Symons had been killed outside Dundee. His earlier statement that it would take over 2 years and 200000 men to win the war now seemed particularly well based. During his short stay in South Africa in 1880 and after the defeat at Majuba where a fellow Scot, General Sir George Colley had been killed, he had developed a healthy respect for the Boers. His was one of the few realistic views held at the time in Britain where the general opinion was that the war would be over by Christmas. Prior to leaving Britain he had written to a friend, David McLaren stating, "I hope the war may not last long, but I am too old at the business not to realise how uncertain war is, especially in South Africa...." (Douglas, 1904:369) Perhaps he was mindful also of the British disaster at the hands of the Zulu's in 1859 at Islandwana in Natal, when close on a thousand British soldiers died in battle.

In spite of being a veteran of many campaigns he was not battle-hardened and always retained a gentle and human touch. His letter of 1 November 1899, written on board the 'Aurania' to his wife contains this passage, "There is a dog on board that reminds me so of Stoney! What wouldn't I give to be back with you and Stoney! ... but every time the screw [ship's propellor Ed] moves I am getting further and further away . .." (Douglas, 1904:380)

What is clear is that Andy Wauchope had no feelings of animosity towards the Boers (or Dutch) as he often referred to them. As already stated he held them in respect and it is interesting to note that his great-uncle had been involved in the occupation of the Cape by the British 90 years previous and had spoken of them (the Dutch) in the highest terms. This is stated in a letter to his friend, David McLaren, just prior to his departure for South Africa. Possibly it sums up in a nutshell his sentiments about South Africa and is therefore quoted in some detail:

“... twenty years after that, my great-uncle Admiral Robert Wauchope was stationed there, and for many years he lived chiefly with his wife at Cape Town, and they knew the Dutch just as much as the British - then there was equality.

We have no feeling against the Dutch if they 


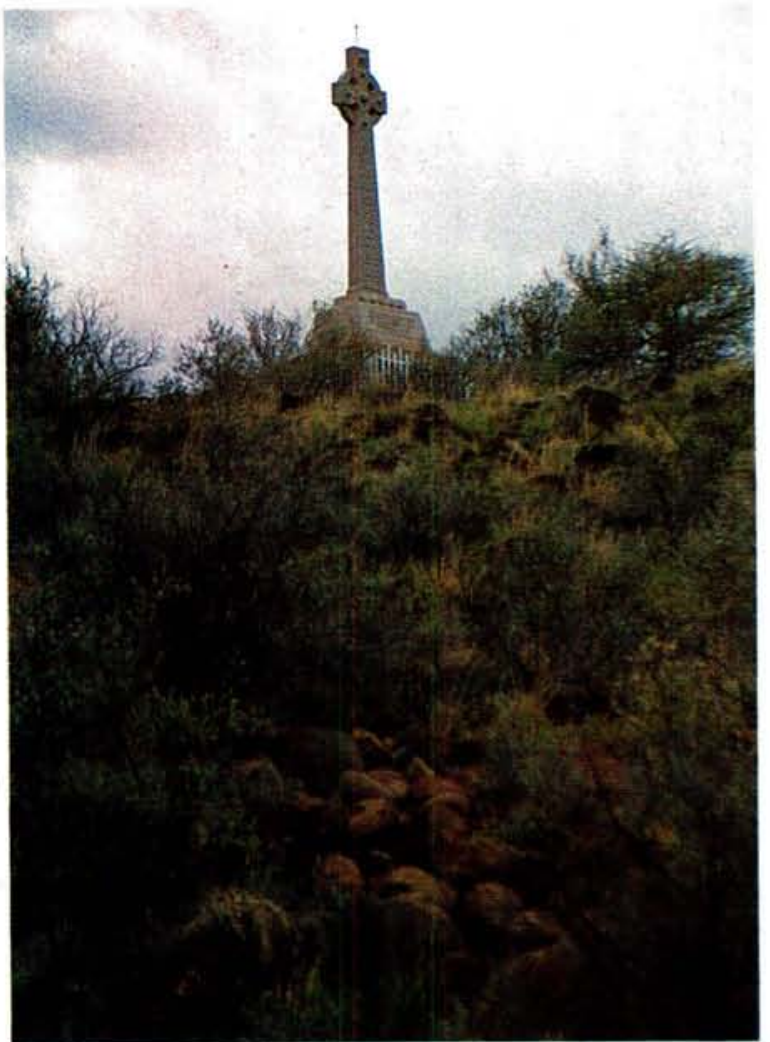

The Highland Brigade memorial at Magersfontein Koppie.

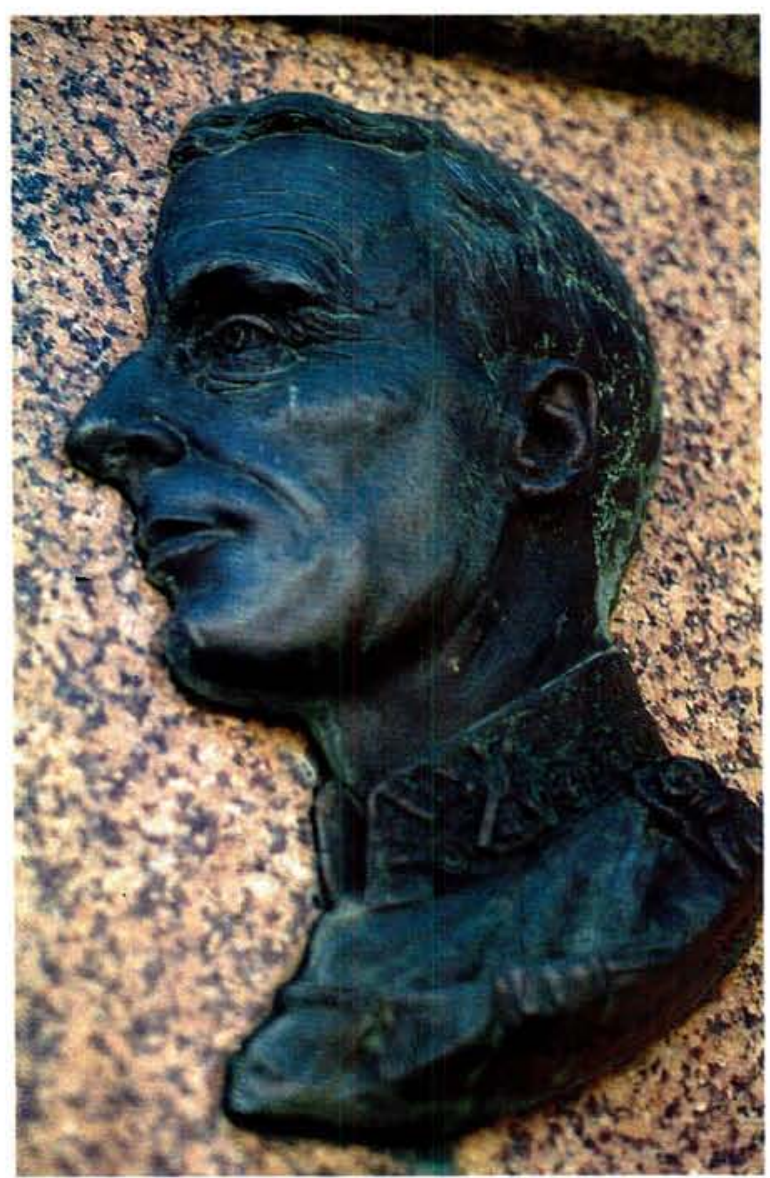

Small plaque attached to Matjiesfontein memorial.

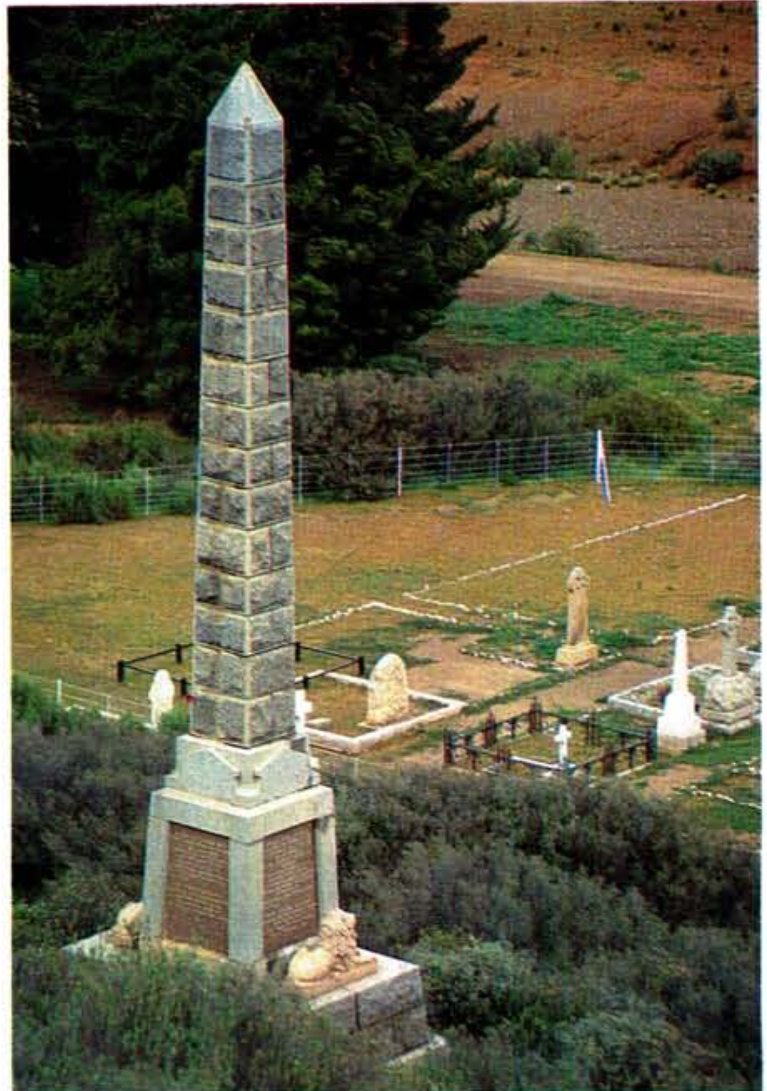

Memorial to Gen Wauchope at Matjiesfontein. His grave can be seen at the rear (the brown sandstone headstone with Celtic cross).

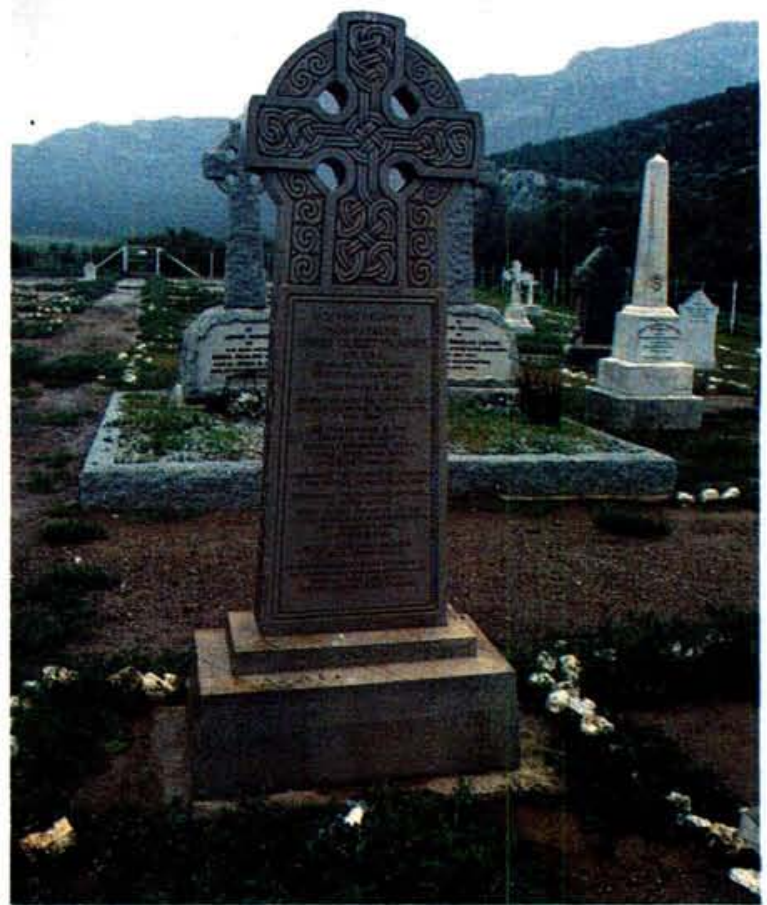

Gravestone at Matjiesfontein cemetary. The double grave of Jimmy Logan and his wife (Celtic crosses) can be seen immediately behind that of Gen Wauchope. 


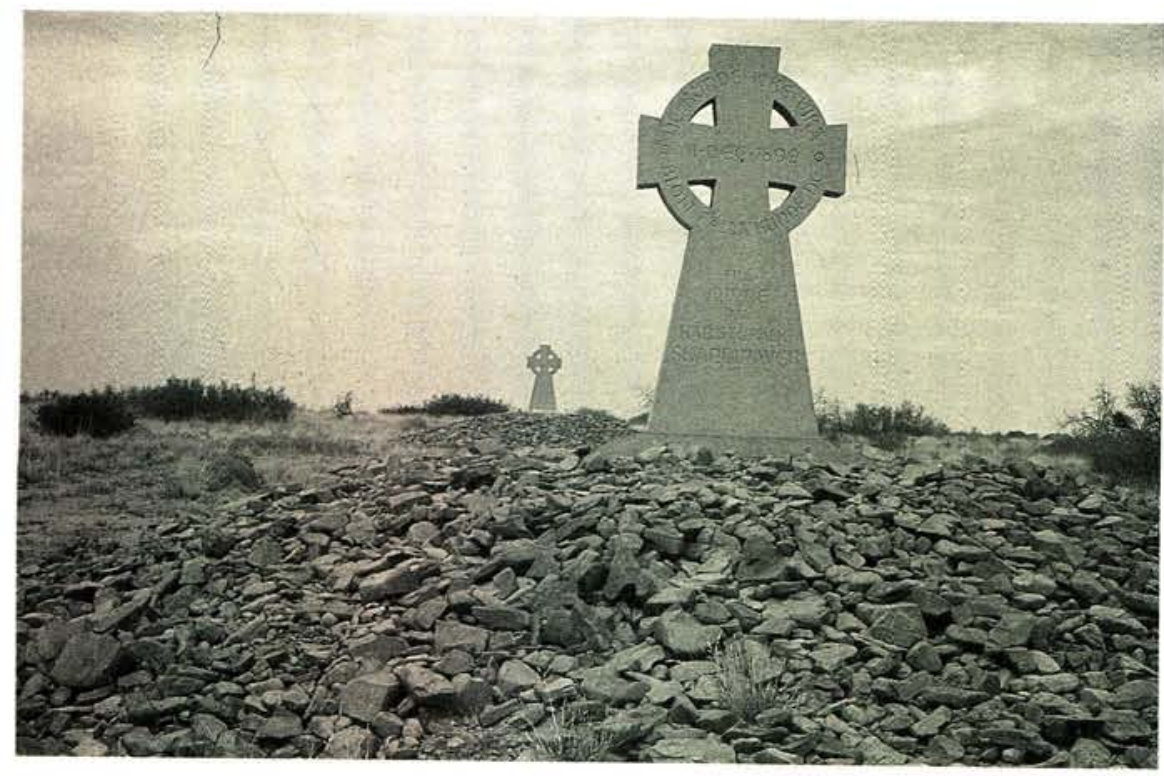

The twin monuments to the Scandinavians killed at their outpost position.

\section{A miniature reconstruction}

of the advance of the

Highland Brigade on Magersfontein hill.

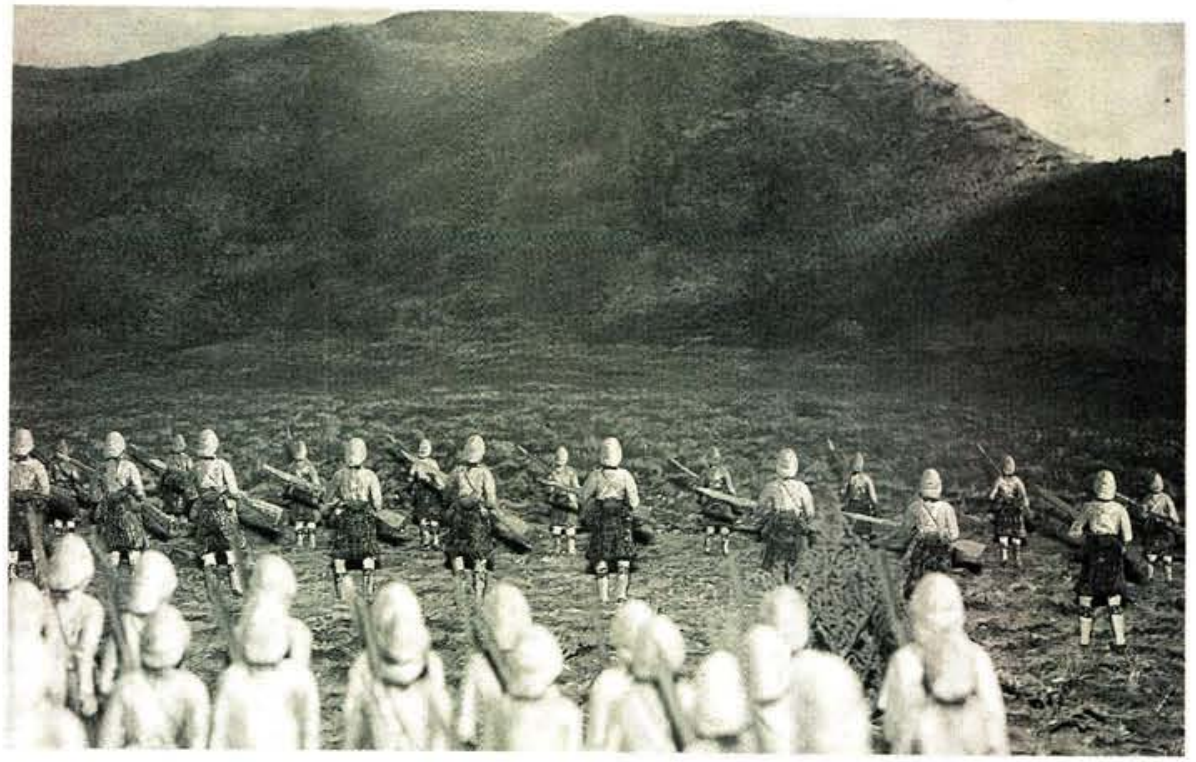

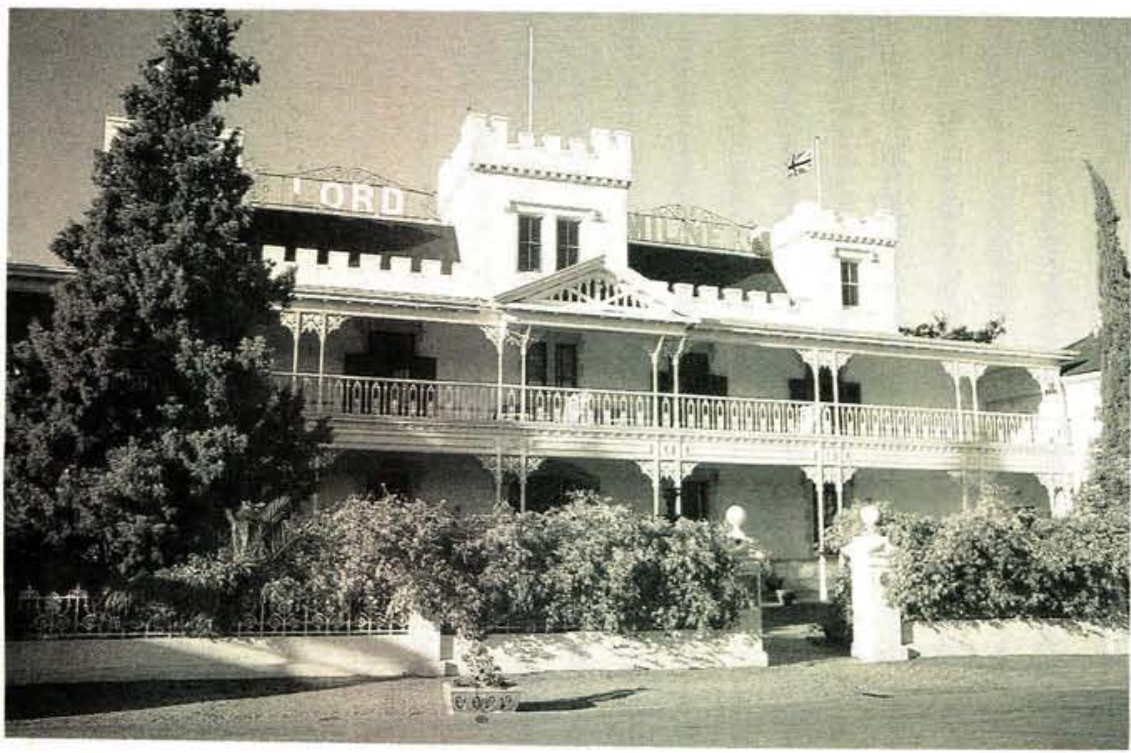

The Lord Milner Hotel at Matjiesfontein built by Jimmy Logan in the early stages of the Boer War. The turret was used as a lookout post, while the hotel became a military hospital. Visitors to the memorial which is $\pm 10 \mathrm{~km}$ away, adjacent to the N3 to Cape Town are advised to enquire at the hotel beforehand in order to gain access to the cemetery. 
will only be so kind as to treat us not as their inferiors but as their equals. I trust the day is very near when we shall be able to be magnanimous, and very magnanimous, after victory.

We were misunderstood when we took that line, as in 1881, after four defeats. - I remain, very sincerely yours,

\section{'A.G. WAUCHOPE.'"} (Douglas 1904:370)

The Aurania arrived in Cape Town on 11 November and a month later on 11 December 1899 General Andrew Gilbert Wauchope lay dead on Magersfontein battlefield.

\section{Magersfontein}

Referred to by his men as 'Andy' or 'Red Mick' (because of his red hair), Wauchope died leading his beloved Black Watch and several other Scottish regiments making up the Highland Brig-

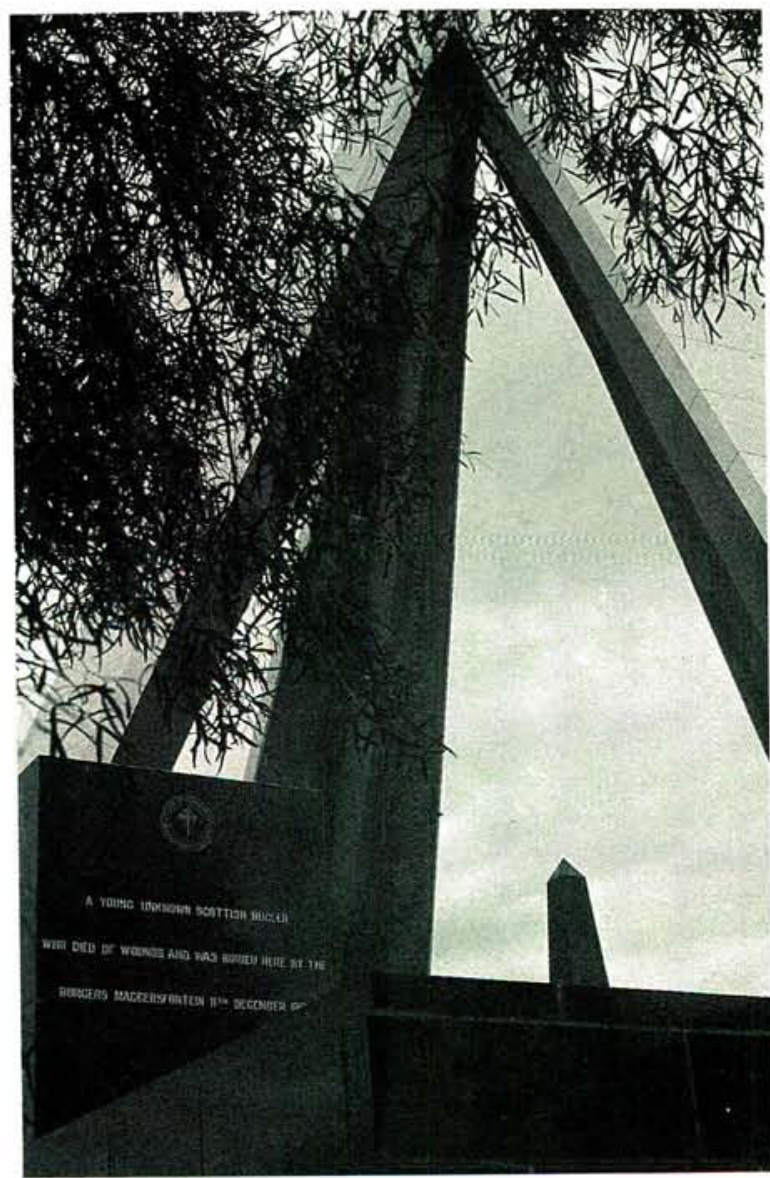

The Boer memorial on the original farm Magersfontein commemorates those Burgers who fell during the battle. It was the scene of a poignent event which took place when a Scottish buglar (a mere lad of about 15) sought shelter after being badly wounded and died there. ade into battle. Much has been written about and speculated upon the battle and the approximately 24 hours which preceded it.

As this is not a tactical treatise, the description of the Magersfontein battle will be suitably short. It has been extensively chronicled in many other publications including a 3 part series in the July, August and September 1967 issues of "Kommando", the forerunner of "Paratus". Two other articles relating to the burial, first at nearby Modder River camp and later at faraway Matjiesfontein, are contained in earlier editions of Paratus. These are "Waar lê die held begrawe?" in the September 1973 issue and "Maj-Genl Wauchope: Where is his grave?" in the November 1973 issue.

In essence there were two basic reasons for the British defeat. Firstly, credit must be given to the Boers for their brilliant concept in "trapping" the British Forces. From the very start of the war the Boers had adapted very quickly to their new military role. In the case of Magersfontein much credit has been given to General Koos de la Rey for the trenches which proved so effective. Secondly, though the British soldiers did not lack courage, their leadership and sometimes outdated tactics were often questionable. Magersfontein was a case in point. General Wauchope is blamed in this respect for giving the order to late for the tightly packed Highland Brigade to deploy - however he was not to know that thousands of Boers were virtually under his feet, secure in their trenches and not beyond in Magersfontein hill as General Methuen had believed.

Briefly, the events were as follows: Methuen's plan was to bombard the Boer forces and then by means of a night march move the Highland Brigade, led by Wauchope close to the Boer positions and attack at dawn. It was a plan which had worked before even though night marches, even for short distances, towards the enemy were considered risky. Several writers have claimed that Wauchope was not happy about the plan but, if so, had not expressed his disagreement with General Methuen under whose command he fell.

The heavy bombardment by the British artillery of Magersfontein "Koppie" merely served as a warning of an impending attack. The Boers some distance ahead of the hill in their trenches suffered no losses. The subsequent night march commenced in pouring rain but the tightly 
packed Scottish regiments plodded on, often delayed by navigational problems and difficult terrain. Nevertheless, they were not much behind schedule when Magersfontein became visible as dawn approached.

Wauchope planned to have his forces as close to Magersfontein hill as possible as this is where the Boers were supposed to be waiting. He gave the order to deploy and this was followed almost immediately by a hail of bullets from the hidden trenches. The Highlanders did not stand a chance. In their massed and only partially deployed state they were an easy target for the intense fire. Although the exact moment of deployment would hardly have affected the outcome of the battle, the fact remained that the British had once again walked into a Boer trap.

General Wauchope, as he walked forward together with his men to inspect the position, was killed instantly. Several of his senior officers including Lt-Col John Coode of the Black Watch and Lt-Col Gerald Goff of the Argylls, also fell. William McFarlan, adjudant of the 2nd Black Watch and Lt Ernest Cox were killed shortly afterwards. Lt-Col Gerald Hughes-Hallett of the Seaforths was the only battalion commander left alive and he was not to know this until later.

The gallant playing of the pipers to rally the men, the arrival of the Gordons later and the fact that several V.C.'s were won, was not enough to turn the tide for the British. They lay pinned down under the burning sun unable to dislodge the Boers in their trenches. It was a victory for the Boers but a bad day for Britain; for Scotland in particular it was a very sad day.

According to Col R. Duxbury, former director of the S.A. National Museum of Military History, there are few accounts that agree on the casualties suffered by both sides. He accepts the figures quoted in the British Official History - 69 officers and 879 other ranks killed, wounded, missing and taken prisoner - of these 45 officers and 702 other ranks were from the Highland Brigade. Of the grand total, 22 officers and 188 other ranks are shown as killed. [Proportionally speaking the number killed was not unduly high - Ed]. The Boer losses are reflected as 87 killed and 188 wounded. (Duxbury, 1979:32) In what is often regarded as the last of the gentlemen's wars it is recorded that Methuen arranged an armistice with the Boer leader, General Cronje, during which the Highlanders returned to collect their wounded and bury their dead and during which the Boers emerged from their trenches and with courtesy and respect offered help where they could.

The week of defeats, Black Week, led to the replacement of Buller by Roberts who embarked for South Africa on December 23, 1899.

\section{Matjiesfontein}

As in the case of General Wauchope's role in the events relating to the battle of Magersfontein, so is there some controversy surrounding his grave. The latter, however, is based on some misunderstanding as the physical facts are there for all to see. It is clearly documented that his original burial place is at Modder River, in the British camp close to Magersfontein. His second funeral came a week later, i.e. on 19 December, 1898 , at Matjiesfontein, approximately $650 \mathrm{~km}$ away after his body had been exhumed and transported there. The article appearing in the November 1973 issue of Paratus and supplied by Miss F.M. Barbour of the Alexander McGregor Memorial Museum at Kimberley quotes the following:

"On December 17 Mr Logan, of Matjiesfontein $\mathrm{CC}$ arrived at Modder with a handsome coffin. It appeared that he had telegraphed to Mrs Wauchope of Niddrie (the General's widow) offering to place a vault at Matjiesfontein at her disposal for the interment of her husband and that she had accepted his offer. We accordingly disinterred the General's body which we had buried at Modder River, and Rennie and $\mathrm{Mr}$ Robertson (Presbyterian Chaplain to the Highland Brigade) accompanied Logan in the train to Matjiesfontein to be present at the reburial". (Unpublished autobiography of Lt Genl Sir Spener Ewart, KCB, then Brigade-Major of the Highland Brigade). At Matjiesfontein a firing party, commanded by Major Woodhead, was provided by the Duke of Edinburgh's Own Volunteer Rifles (the "Dukes"), who were guarding the railway in the Matjiesfontein area.

Maj-Genl Wauchope's own Regiment (the Black Watch) have always believed that Logan did send the widow a telegram, as suggested by Ewart, but that owing to the various spellings of "Magersfontein" then current, she accepted without knowing that there were two places, Magersfontein and Matjiesfontein, some 650 kilometres apart." 


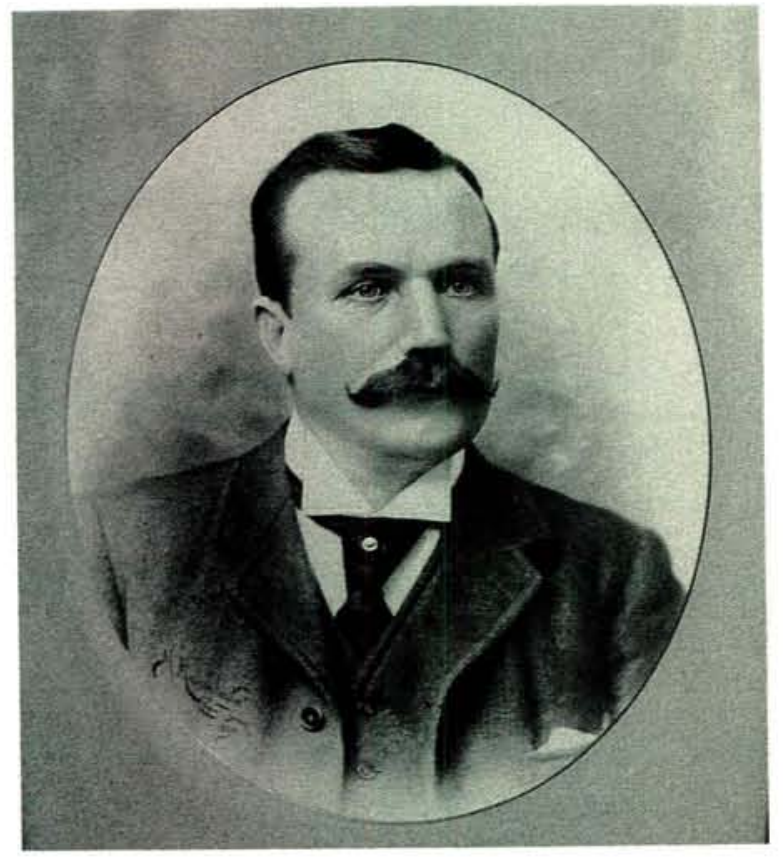

Mr J.D. (Jimmie) Logan who established and developed Matjiesfontein into a functional, self-contained village. He later entered politics and became M.L.A. for the North West Cape. Olive Schreiner, the South African writer, rented a villa there which became known as Schreiners Cottage and many other celebrities such as Cecil John Rhodes stayed at Jimmy Logan's hotel. The Lord Milner Hotel, as it is called (where this portrait is on display in the small museum), together with the adjoining buildings which make up the village, is conveniently sited for both rail and road users.

It remains in vogue, a distinction it first achieved at the turn of the century.

It is as well to leave it at that and believe that these actions were done with the best of intentions including those of fellow Scot Jimmy Logan known as the Laird of Matjiesfontein as Miss Barbour says in concluding her article:

"Quite apart from his widow's expressed wishes, the other British dead from Modder
River and Magersfontein have all been removed to Kimberley so that a second reburial, at either of these sites would leave the General in even greater isolation than at present.

His name is commemorated on the Black Watch memorial at Magersfontein, and his original burial place at Modder River will be marked. His removal to Matjiesfontein has become part of our South African history and with the Field Museum now open on the battlefield there need be no fear that Scotland's hero will be forgotton at the site where his military career was so abruptly ended."

Apart from the suitably dignified yet striking gravestone where Andy Wauchope lies buried in the small cemetery near Matjiesfontein, which incidentally is now also shared by Jimmy Logan and his wife, there is a magnificent memorial on the slope of the hill immediately adjacent to the cemetery. In summer the hill is covered in Cape Karoo flowers, many of which are similar to the yellow gorse and bluebells found in the Scottish Highlands.

It is a fitting resting place indeed for a gallant and noble soldier.

${ }^{\star}$ Eric McPherson B.A., Editor Militaria

\section{BIBLIOGRAPHY}

Baird, William, General Wauchope, Oliphant, Anderson and Ferrier. Edinburgh, 1902

Douglas, Sir George. The Life of Major-General Wauchope, Hodder and Stoughton, London, 1904.

Doyle, Conan, The Great Boer War, First Edition 1900.

Duxbury, George R., The Battle of Magersfontein S.A. National Museum of Military History, Johannesburg 1979.

Robinson, Commander Chas N., R.N. Celebrities of the Army, George Newnes, London. 1900. (Portrait of Gen Wauchope.)

S.A. Biografiese Woordeboek Deel II Tafelberg, Kaapstad, 1972.

Photographs, including copies of portraits, taken by author. 